\title{
Pemahaman Usaha Mikro Kecil Menengah Terhadap Penerapan Peraturan Pemerintah No. 23 Tahun 2018 Tentang Penurunan Tarif Pajak Penghasilan
}

\author{
Gunawan Hartadi ${ }^{1}$, Bambang Suryono ${ }^{2}$, Titik Mildawati ${ }^{3}$ \\ ${ }^{1,2,3}$ Sekolah Tinggi Ilmu Ekonomi Indonesia (STIESIA) Surabaya \\ *Email korespondensi: gunh2323@gmail.com
}

\begin{abstract}
UMKM is considered as one of primary contributors to state revenue. Due to its largest tax contributor, UMKM, the Small-Medium Enterprises (SMES), is authorised by government perceiving distinctive final income tax. Since July 1st 2018, its income tax changed from 1\% of gross turnover to $0.5 \%$ owing to a regulation PP No. 23 of 2018. Therefore, this study aimed to investigate the impact of PP No. 23 of 2018 application on the SMEs' desires to expand their business. Through this regulation, the calculation of income tax for SMEs has been converted $1 \%$ of gross turnover to $0.5 \%$. This study applied qualitative research with an expectancy theory. In this study, the interviews were conducted to three informants. As the results, this study indicated that the government regulation assisted improving the desires of SMES to escalate their businesses. Then, the SMES generally did not understand the new regulations due to lack of socialization about PP No. 23 of 2018. Moreover, the regulation was identified as an encouragement so that SMEs would not divert into online sales system. Thus, the respondents running SMEs suggested the government to synchronize both central and regional regulations so that SMEs sectors could be increased rapidly.
\end{abstract}

Keywords: PP No. 23 of 2018, expectancy theory, online systems, regulation synchronization

Saran sitasi: Hartadi, G., Suryono, B., \& Mildawati, T. (2020). Pemahaman Usaha Mikro Kecil Menengah Terhadap Penerapan Peraturan Pemerintah No. 23 Tahun 2018 Tentang Penurunan Tarif Pajak Penghasilan. Jurnal Akuntansi dan Pajak, 21 (1), 1-13. doi: http://dx.doi.org/10.29040/jap.v21i1.824

DOI: http://dx.doi.org/10.29040/jap.v21i1.824

\section{PENDAHULUAN}

\section{Latar Belakang Masalah}

Penerimaan pajak merupakan sumber penerimaan negara yang utama dan paling besar, menyumbang sekitar $70 \%$ dari seluruh penerimaan negara (Pusat Kajian Anggaran, Badan Keahlian DPR RI). Dikarenakan oleh pentingnya besaran penerimaan pajak ini maka target penerimaan dari sektor pajak yang ditentukan oleh pemerintah pusat kepada Direktorat Jenderal Pajak selalu mengalami peningkatan dari tahun ke tahun. Dengan demikian sistem perpajakan terus disempurnakan, pemungutan pajak diintensifkan, dan aparat perpajakan/pengelola juga harus mampu dan bersih sehingga dapat mewujudkan realisasi beban target yang telah ditetapkan. Menurut laporan tahunan Kementerian Koperasi dan Usaha Kecil Menengah (KKUKM) tahun 2015 jumlah UMKM di Indonesia sebanyak 57.895.721 unit dan menyerap tenaga kerja sebanyak
114.144.082 orang maka sektor UMKM berpotensi untuk menjadi penyumbang pajak utama di Indonesia. Sedangkan berdasarkan data Biro Pusat Statistik (BPS) pada tahun 2011-2013, UMKM secara konstan menyumbang kontribusi sebesar kurang lebih 55\% untuk PDB (Produk domestik bruto) sedangkan kontribusinya terhadap pajak tidak maksimal.

Segala kelebihan yang ditawarkan oleh usaha jenis ini tidak diimbangi dengan kesadaran pelakunya, banyak pelaku UMKM cenderung tidak mau menunjukkan data riil yang dimilikinya kepada dirjen pajak (Prawagis, 2016). Ketakutan yang dialami oleh pelaku UMKM ini didukung dengan data di lapangan yang menunjukkan banyak tumpang tindih peraturan antara pusat dan daerah sehingga memberi kesan mempersulit perijinan UMKM dan menurunkan minat pelaku UMKM untuk melaporkan pajaknya serta manfaat yang tidak langsung dapat dirasakan oleh pelaku UMKM setelah melaporkan 
dan membayar pajaknya sebagai akibat dari kurangnya sosialisasi pada pelaku dan pegiat usaha jenis ini (Ananda et al, 2015). Di sisi lain, pelaku UMKM juga menginginkan terwujudnya pemerintahan yang good governance dan memberikan penjelasan kepada masyarakat luas mengenai alokasi penggunaan uang pajak (Syahdan, 2014).

Berdasarkan Peraturan Pemerintah Nomor 46 tahun 2013 yang terbit tanggal 12 Juni 2013 dan mulai berlaku 1 Juli 2013 menerangkan bahwa Dasar Pengenaan Pajak (DPP) yang digunakan untuk menghitung $\mathrm{PPh}$ final untuk jenis usaha ini adalah omset setiap bulan. Wajib Pajak (WP) akan membayar PPh final sebesar $1 \%$ (satu persen) dari omset bulanannya. Dari beberapa hasil penelitian yang menunjukkan kesulitan atau kelemahan UMKM dalam menyusun laporan keuangan, maka akan membawa dampak dalam menentukan jumlah penghasilan kena pajak, bahkan ada beberapa pelaku UMKM menggunakan jasa konsultan untuk menghitung dan melaporkan pajak mereka (Novliemyanti, 2017). Kesulitan dalam menghitung pajak terutang merupakan salah satu yang sering dikeluhkan masyarakat bila berhubungan dengan kantor pajak. Berdasarkan fenomena yang berkembang di masyarakat menunjukkan bahwa UMKM masih sederhana dalam hal perlakuan akuntansinya, maka kemungkinan besar terdapat berbagai penafsiran atau penginterpretasian terhadap kewajiban perpajakannya (Susilo, 2014).

Penerapan PP No. 46 Tahun 2013 inipun kurang memberikan kontribusi dalam penambahan wajib pajak baru karena PP ini masih memberikan hasil yang fluktuatif dalam hal penerimaan $\mathrm{PPh}$ final (Keziana, 2016). Wajib pajak yang seharusnya memanfaatkan kebijakan ini masih belum mengetahui tentang penyederhanaan penghitungan $\mathrm{PPh}$ ini. Kurangnya sosialisasi dan pendapat masyarakat yang berpikiran bahwa hasil dari setoran pajak tidak ia rasakan secara langsung turut serta menjadi latar belakang kurang maksimalnya penerapan PP baru ini (Huda, 2015).

Sebagai langkah pemerintah untuk mendukung tumbuh kembangnya ekonomi kerakyatan maka setelah mengeluarkan PP no. 46 tahun 2013, pada tahun 2018, Direktorat Jendral Pajak melakukan terobosan di sektor perpajakan UMKM melalui Peraturan Pemerintah (PP) Nomor 23 Tahun 2018 tentang Pajak Penghasilan atas Penghasilan dari
Usaha yang Diterima atau Diperoleh Wajib Pajak yang Memiliki Peredaran Bruto Tertentu sebagai pengganti atas Peraturan Pemerintah Nomor 46 Tahun 2013. PP ini berlaku efektif 1 Juli 2018, dengan pemberlakuan PP ini diharapkan beban pajak yang ditanggung oleh pelaku UMKM menjadi lebih kecil, sehingga pelaku UMKM memiliki kemampuan ekonomi yang lebih besar untuk mengembangkan usaha dan melakukan investasi karena tarif pajak UMKM menjadi salah satu faktor utama yang mempengaruhi kepatuhan wajib pajak UMKM (Resyniar, 2014); (Prawagis, 2016). Melalui PP ini pula pemerintah memberlakukan peraturan baru mengenai jangka waktu pengenaan tarif $\mathrm{PPh}$ final $0,5 \%$ yaitu untuk WP pribadi diberikan jangka waktu 7 tahun, WP Badan berbentuk koperasi, CV, dan Firma diberikan jangka waktu 4 tahun, dan WP Badan yang berbentuk PT ( Perseroan Terbatas ) diberikan jangka waktu 3 tahun.

Dengan diberlakukannya tarif pajak penghasilan baru yang lebih kecil dari ketetapan tarif sebelumnya maka para pelaku UMKM diharapkan dapat segera berbenah dan melaksanakan kewajibannya sebagai warganegara yang baik. Menurut teori akuntansi keperilakuan yaitu Expectancy Theory yang dikemukakan oleh Victor Vroom pada bukunya Work and Motivation (1964), penurunan tarif pajak akan meningkatkan minat pelaku usaha untuk bekerja semakin giat, karena pelaku pajak memiliki ekspektasi bahwa keuntungan yang ia terima semakin besar karena semakin kecil beban yang harus ia terima untuk menyelesaikan kewajibannya sebagai warganegara. Berdasarkan latar belakang masalah di atas, maka penelitian ini dilakukan untuk mengetahui bagaimanakah pemahaman pelaku UMKM terhadap kebijakan pemangkasan tarif pajak ini, apakah pemangkasan tarif pajak ini memberikan daya tarik bagi pelaku usaha UMKM untuk meningkatkan usahanya. Berdasarkan hal tersebut, maka peneliti melakukan penelitian dengan mengambil judul "PEMAHAMAN USAHA MIKRO KECIL MENENGAH (UMKM) TERHADAP PENERAPAN PP No. 23 TAHUN 2018 TENTANG PENURUNAN TARIF PAJAK PENGHASILAN".

\section{Rumusan Masalah}

Dengan telah berlakunya PP No. 23 tahun 2018, kegiatan UMKM yang berdasar pada ekonomi kerakyatan dimana ekonomi kerakyatan adalah sistem perekonomian yang dibangun pada kekuatan ekonomi 
rakyat. Berangkat dari latar belakang penelitian yang telah dijabarkan di atas, maka pokok masalah yang dirumuskan dalam penelitian ini adalah: Bagaimanakah pemahaman pelaku UMKM terhadap penerapan PP No. 23 Tahun 2018 dan bagaimanakah respon serta harapan para pelaku UMKM?

\section{Tujuan Penelitian}

Berdasarkan rumusan masalah di atas, maka tujuan penelitian ini adalah:

1. Untuk memahami bagaimanakah penerapan PP No. 23 tahun 2018 ini memberikan efek pada minat pelaku UMKM untuk meningkatkan dan memperluas usaha mereka.

2. Untuk memahami bagaimanakah respon dan harapan pelaku usaha UMKM mengenai implementasi peraturan baru ini.

\section{METODE PENELITIAN}

\section{Pendekatan Penelitian}

Penelitian ini menggunakan metode penelitian kualitatif yaitu penelitian yang bertujuan untuk membangun suatu proposisi dan menjelaskan makna di balik realita sosial yang terjadi. Penelitian ini menggunakan pendekatan fenomenologi. Penelitian ini berusaha melihat fenomena yang sesungguhnya terjadi, memandang apa yang dipahami oleh informan tentang pajak dan implikasinya. Penelitian fenomenologi pada hakekatnya adalah berhubungan dengan interpretasi terhadap realitas. Fenomenologi mencari jawaban tentang makna dari suatu fenomena. Pada dasarnya, ada dua hal utama yang menjadi fokus dalam penelitian fenomenologi yakni:

1. Textual description: apa yang dialami oleh subjek penelitian tentang sebuah fenomena. Apa yang dialami adalah aspek objektif, data yang bersifat faktual, hal yang terjadi secara empiris.

2. Structural description: bagaimana subjek mengalami dan memaknai pengalamannya. Deskripsi ini berisi aspek subjektif. Aspek ini menyangkut pendapat, penilaian, perasaan, harapan, serta respons subjektif lainnya dari subjek penelitian berkaitan dengan pengalamannya itu.

Peneliti menggunakan pendekatan fenomenologi karena peneliti ingin memahami bagaimana subjek penelitian (dalam hal ini pelaku UMKM) menghadapi dan merespon penurunan tarif pajak yang mulai diberlakukan pada tahun 2018. Hal ini menjadi suatu fenomena karena pada umumnya suatu negara ingin meningkatkan pendapatannya melalui kebijakan peningkatan tarif pajak, akan tetapi mengapa dalam hal ini justru negara menurunkan tarif pajak pada sektor yang menjadi salah satu penyumbang pajak terbesar yaitu sebesar 5,37 triliun rupiah pada tahun 2018 (insight.kontan.co.id). Dengan penurunan ini pemerintah berharap meningkatnya pendapatan dari sektor UMKM karena tarif pajak yang semakin terjangkau dan kesejahteraan dari para pengusaha UMKM dapat meningkat.

Penelitian yang menggunakan pendekatan kualitatif yang menjadi alat utama adalah manusia, artinya melibatkan penelitinya sendiri sebagai instrumen, dengan memperhatikan kemampuan peneliti dalam hal bertanya, melacak, mengamati, memahami dan mengabstraksikan sebagai alat penting yang tidak dapat diganti dengan cara lain. Oleh karena itu, peneliti harus memiliki bekal teori dan wawasan yang luas jadi bisa bertanya, menganalisis, dan mengkonstruksi objek yang diteliti menjadi lebih jelas. Selain itu, peneliti wajib hadir di lapangan menemukan data-data yang diperlukan yang berkesinambungan langsung ataupun tidak langsung dengan masalah yang diteliti, dimana dalam penelitian ini penulis tidak menentukan waktu lamanya atau harinya, tetapi peneliti secara terus menerus menggali informasi data dalam keadaan yang tepat dan sesuai dengan kesempatan dan kesepakatan para informan.

Dalam penelitian kualitatif, yang menjadi instrumen atau alat penelitian adalah peneliti itu sendiri. Dalam penelitian kualitatif, pada awalnya dimana permasalahan belum jelas dan pasti, maka yang menjadi instrumen adalah peneliti sendiri.

\section{Subjek Penelitian}

Batasan subjek penelitian adalah benda, hal atau orang tempat data untuk variabel penelitian melekat, dan yang di permasalahkan (Suharsimi Arikunto, 2016: 26). Dalam sebuah penelitian, subjek penelitian mempunyai peran yang sangat strategis karena pada subjek penelitian itulah data tentang variabel yang akan diteliti. Pada penelitian kualitatif, responden atau subjek penelitian disebut dengan istilah informan, yaitu orang memberi informasi tentang data yang diinginkan peneliti berkaitan dengan penelitian yang sedang dilaksanakan.

Adapun subjek penelitian dalam penelitian ini adalah pemilik UMKM di kota Surabaya sebanyak 3 orang. Peneliti memilih pemilik UMKM sebagai 
informan dengan alasan pemilik merupakan orang yang mengetahui tentang segala yang berkaitan dengan usahanya khususnya dalam hal ini adalah mengenai pajak. Alasan peneliti memilih 3 informan ini karena mereka berasal dari bidang UMKM yang berbeda-beda, yaitu: kuliner, asesoris, dan distributor sehingga peneliti dapat memperoleh hasil wawancara yang bervariasi dari berbagai bidang usaha.

\section{Informan Penelitian}

Informan Penelitian adalah subyek yang memahami informasi objek penelitian sebagai pelaku maupun orang lain yang memahami objek penelitian (Nazir M., 2005: 55). Teknik sampling yang digunakan dalam penelitian ini adalah purposive sampling yaitu teknik pengambilan sampel sumber data dengan pertimbangan tertentu, misalnya orang yang dianggap paling tahu tentang apa yang kita harapakan atau mungkin sebagai penguasa sehingga akan memudahkan peneliti menjelajahi objek atau situasi sosial yang akan diteliti (Sugiyono, 2016: 219). Penelitian kualitatif dalam menentukan sampel tidak berfokus pada jumlah sampel yang besar, tidak kaku, melainkan dapat berubah sesuai dengan pemahaman konseptual yang berkembang, dan diarahkan pada kecocokan konteks. Adapun kriteria pemilihan informan dijelaskan sebagai berikut:

1. Mempunyai NPWP aktif, hal ini diperlukan agar peneliti yakin bahwa informan dapat mewakili penyetor pajak UMKM aktif sehingga informan mengetahui proses pelaporan dan penyetoran pajak penghasilan.

2. Sudah memiliki UMKM selama lebih dari 3 tahun agar informan mengetahui perubahanperubahan peraturan mengenai tarif pajak dari PP no. 46 tahun 2013 ke PP no. 23 tahun 2018.

3. Memiliki omset penjualan dibawah 4,8 milyar pertahun sebagai syarat utama usahanya masuk kategori UMKM.

Informan yang diwawancarai dalam penelitian ini adalah sebagai berikut:

1. Bu Y sebagai pemilik UMKM yang bergerak di bidang kuliner (restoran), memiliki karyawan sebanyak 34 orang, memiliki cabang usaha di 7 lokasi di Surabaya dan sudah melakukan usaha ini sejak tahun 2010 hingga sekarang.

2. Pak CR sebagai pemilik UMKM yang bergerak di bidang asesoris perhiasan, memiliki 2 tempat usaha di Pusat Grosir Surabaya, memiliki karyawan sebanyak 16 orang dan sudah berkecimpung di bidang ini sejak tahun 2008 .

3. Pak $\mathrm{CH}$ sebagai pemilik UMKM yang bergerak di bidang distributor gelas / barang pecah belah, memiliki 1 tempat usaha di Pusat Grosir Surabaya, memiliki karyawan sebanyak 8 orang dan sudah melakukan usaha ini sejak 2015.

\section{Satuan Kajian}

Dalam penelitian ini satuan kajian yang digunakan oleh peneliti adalah perilaku atau respon pelaku usaha UMKM di wilayah Jawa Timur khususnya kota Surabaya terhadap pemberlakuan peraturan pemerintah yang baru dan diharapkan dapat membantu perkembangan UMKM di masa depan. Penelitian ini akan membahas mengenai sikap dari pelaku usaha mengenai peraturan baru dari pemerintah pusat yaitu PP No. 23 tahun 2018, apakah peraturan baru ini membawa angin segar bagi penambahan wajib pajak baru dan bagi semangat bekerja pelaku usaha UMKM. Surabaya digunakan karena menurut data dari BPS, di provinsi Jawa Timur merupakan daerah yang memiliki populasi UMKM terbesar ke 3 di Indonesia, dan Surabaya merupakan ibukota Jawa Timur.

\section{Metode Pengumpulan Data}

Jenis data yang digunakan dalam penelitian ini adalah data primer, dimana data primer diartikan sebagai data yang dikumpulkan sendiri oleh perorangan/suatu organisasi secara langsung dari objek yang diteliti dan untuk kepentingan studi yang bersangkutan yang dapat berupa interview dan observasi. Dalam menyusun penelitian ini, data primer yang digunakan adalah wawancara yang dilakukan kepada pemilik UMKM di Surabaya sedangkan observasinya langsung kepada tempat usaha informan.

Teknik pengumpulan data merupakan cara mengumpulkan data yang dibutuhkan untuk menjawab rumusan masalah penelitian. Teknik pengumpulan data yang digunakan peneliti dalam penelitian ini adalah sebagai berikut:

1. Wawancara

Wawancara merupakan salah satu teknik pengumpulan data yang dilakukan dengan berhadapan secara langsung dengan yang diwawancarai tetapi dapat juga diberikan daftar pertanyaan dahulu untuk dijawab pada kesempatan lain. Jenis wawancara yang digunakan peneliti dalam 
penelitian ini adalah wawancara mendalam (in-depth interview). Wawancara terstruktur digunakan karena para informan dalam penelitian ini memiliki waktu senggang yang terbatas, sehingga dalam waktu yang sedikit tersebut peneliti bisa mendapat jawaban atas rumusan permasalahan dalam penelitian ini. Untuk melengkapi data yang akurat dan tepat, maka terlebih dahulu dibuat pedoman wawancara. Hal ini dimaksudkan agar dalam pelaksanan wawancara tersebut dapat terarah pada pokok permasalahan yang telah dirumuskan. Jadwal wawancara informan sebagai berikut: Bu Y dilakukan wawancara pada tanggal 20 April 2019 selama 26 menit, Pak CR dilakukan wawancara pada tanggal 27 April 2019 selama 31 menit, sedangkan Pak CH dilakukan wawancara pada tanggal 26 Mei 2019 selama 16 menit.

2. Observasi

Penelitian ini menggunakan observasi partisipasi pasif. Dimana dalam penelitian ini peneliti datang di tempat kegiatan orang yang diamati tetapi tidak ikut terlibat dalam kegiatan tersebut. Dalam penelitian ini, observasi dilakukan pada tempat kegiatan usaha pelaku UMKM.

\section{Teknik Analisa Data}

Miles dan Huberman (1992), mengemukakan bahwa aktivitas dalam analisis data kualitatif dilakukan secara interaktif dan berlangsung secara terus menerus sampai tuntas, sehingga datanya sudah jenuh. Aktivitas dalam analisis data, yaitu data reduction, data display, dan conclusion drawing/verification. Penjelasan dari setiap aktivitas tersebut adalah:

1. Reduksi Data (Data Reduction)

Peneliti memilah hasil wawancara dengan para informan sesuai dengan fakta dan kebutuhan penelitian, sehingga dapat di hasilkan data-data yang di butuhkan peneliti. Dalam penelitian ini, peneliti membuang keterangan dari informan yang tidak berhubungan dengan pokok bahasan dan menyederhanakan pertanyaan yang diajukan kepada informan menjadi 6 pertanyaan penting. Dengan mereduksi data hasil wawancara dan pertanyaan yang diajukan pada informan diharapkan hasil penelitian dapat terfokus pada tujuan dibuatnya penelitian ini.

2. Penyajian Data (Data Display)

Peneliti menggunakan hasil wawancara yang telah direduksi serta dokumentasi sebagai sekumpulan informasi peneliti dalam menyusun penyajian data. Kemudian hasil itu disusun dan dituangkan dalam bentuk tulisan teks narasi agar mudah dipahami oleh peneliti berikutnya. Dalam penelitian ini, peneliti menuliskan hasil wawancara dari para informan sesuai dengan yang diucapkan oleh para informan sehingga banyak ejaan yang tidak baku akan tetapi hal ini tidak mengurangi intisari dari pernyataan yang diberikan oleh para informan.

3. Penarikan Kesimpulan (Conclusion verification) Dalam penarikan kesimpulan peneliti meringkas hasil wawancara dengan informan yaitu pelaku usaha UMKM, kemudian hasil ringkasan tersebut disimpulkan sesuai dengan fakta di lapangan dan tujuan penelitian, sehingga makna-makna yang muncul sesuai dengan kebenarannya, kondisi di masyarakat saat ini, dan tren yang sedang terjadi. Peneliti juga menggunakan hasil penelitian terdahulu sebagai pertimbangan dalam menarik kesimpulan dan menjustifikasi setiap kesimpulan yang didapat.

\section{HASIL DAN PEMBAHASAN}

Pada bagian ini akan dijelaskan hasil interpretasi atas pemahaman pelaku UMKM terhadap penerapan PP no. 23 tahun 2018 yaitu:

Tingkat pemahaman pelaku UMKM akan penerapan PP No. 23 tahun 2018.

Penerapan peraturan baru dari pemerintah memerlukan sosialisasi yang meluas bagi para stakeholder karena sosialisasi dan pemahaman pelaku UMKM terhadap perpajakan memiliki pengaruh yang signifikan terhadap kepatuhan wajib pajak (Ananda, 2015). Seringkali terjadi bahwa sosialisasi yang dilakukan oleh pemerintah kurang bisa tepat sasaran ke target yang dituju. Banyak sekali faktor-faktor yang menjadi penghalang bagi pemerintah untuk bisa memberikan pemahaman kepada stakeholder yang menjadi sasaran sosialisasi, antara lain: kurangnya latar belakang pendidikan penerima informasi, sedikitnya waktu sosialisasi, kurang maksimalnya metode sosialisasi, dan lain sebagainya.

Berdasarkan teori motivasi pengharapan Vroom dengan diberlakukannya peraturan baru yang memperingan kewajiban dari pelaku UMKM untuk membayar kepada negara maka seharusnya pelaku UMKM akan berusaha mencari informasi mengenai kebijakan baru ini. Walaupun tidak dibantu oleh sosialisasi dari pemerintah, pelaku UMKM akan 
mencari informasi melalui kanal-kanal berita yang ada.

Dalam wawancara yang dilakukan kepada para informan diperoleh hasil sebagai berikut:

"Tau sih..., tapi saya belum ngerti $100 \%$ isi sama syaratnya, biasane aku konsultasi dulu sama temenku yang konsultan pajak. Soal'e biasa'e bahasa undang-undang itu kan agak mbulet gitu ya.. Takut'e salah nanti." (Sdri. Y, pengusaha kuliner)

Sedangkan pelaku UMKM di bidang asesoris memberikan pernyataan sebagai berikut:

"Baru tau ini, biasanya pake jasa konsultan pajak sih... yang ngurus juga dia (konsultan pajak). Karena kalau ngurus dewe atau lewat online gitu takut salah sih, iya.. kurang sosialisasi ya.. cuma pasang spanduk tok, itu aja aku liatnya didaerah juanda sana." (Sdr. CR, pengusaha asesoris)

Kurangnya sosialisasi ditengarai sebagai faktor utama kurangnya pemahaman pelaku UMKM terhadap peraturan baru ini. Selain itu, pelaku UMKM masih merasa awam terhadap ketentuan perpajakan di Indonesia, kemungkinan hal ini disebabkan karena banyaknya informasi yang simpang siur di kalangan pengusaha UMKM yang menyebabkan ketakutan pelaku UMKM jika berhadapan dengan perpajakan. Padahal pemahaman akan kewajiban perpajakan memiliki pengaruh yang signifikan terhadap kepatuhan wajib pajak (Prajogo, 2013). Pelaku UMKM dari bidang distributor gelas memberikan pernyataan sebagai berikut:

"Pernah liat pengumumannya aja tapi belum tahu sistemnya gimana sama syaratnya apa aja, biasanya kan banyak tuh syarat sama ketentuannya. Sementara saya lihat dulu perkembangannya gimana, sama nunggu kabar dari temen UMKM juga ajah yang sudah lapor duluan." (Sdr. CH, distributor gelas)

Dari keterangan para pelaku UMKM, dapat disimpulkan bahwa sosialisasi tentang PP No. 23 tahun 2018 tentang penurunan tarif pajak penghasilan terhadap UMKM ini kurang maksimal dilakukan. Mereka tidak mendapat penjelasan secara mendalam dari dirjen pajak tentang ketentuan baru ini. Bahkan 2 dari 3 informan menyerahkan urusan perpajakan mereka kepada konsultan pajak, karena mereka enggan untuk mengurus sendiri pajak penghasilan yang harus mereka bayarkan meskipun pemerintah telah memberikan kemudahan lewat sistem pelaporan pajak secara online. Dalam pemahaman pelaku UMKM, perpajakan itu hal yang ribet sehingga mereka lebih percaya kepada konsultan pajak untuk menghitung dan melaporkan pajak mereka (Novliemyanti, 2017).

Dengan data ini pula dapat disimpulkan bahwa teori motivasi pengharapan Vroom tidak berlaku, karena pelaku UMKM cenderung lebih pasif dalam mencari informasi mengenai peraturan baru yang iterapkan. Hal ini dapat juga disebabkan karena latar belakang pendidikan mayoritas pengusaha UMKM tidak terlalu tinggi dan kurangnya pemahaman akan pasal-pasal dalam peraturan yang berlaku, hal ini mendukung temuan penelitian sebelumnya dimana disimpulkan bahwa pelaku UMKM umumnya merupakan masyarakat yang tidak memiliki pengetahuan yang luas dalam perundang-undangan yang berlaku dalam bidang mereka dikarenakan pada umumnya mereka tidak berasal dari kalangan profesional atau berpendidikan tinggi sehingga mayoritas memiliki keterbatasan dalam pemahaman kewajiban perpajakan mereka (Susilo, 2014).

Dengan perubahan tarif melalui PP no. 23 tahun 2018 maka seharusnya memberikan efek positif pada pelaku UMKM karena tarif pajak penghasilan mereka mengalami penurunan. Dengan demikian seturut dengan berjalannya waktu maka dirjen pajak telah berbenah dengan penyederhanaan sistem pelaporan pajak dan pengurangan tarif sehingga hasil penelitian terdahulu yang dilakukan oleh peneliti sebelumnya dapat diperbaiki.

Pemahaman pelaku UMKM akan penerapan PP No. 23 tahun 2018 yang bertujuan untuk menarik minat pelaku UMKM dalam membayar pajak penghasilan mereka.

Dengan penerapan PP No. 23 tahun 2018 diharapkan pelaku UMKM tertarik untuk memperbaiki cara kerja mereka dan melaporkan besaran pajak terutang karena besaran tarif pajak berkurang separuhnya. Pada hasil wawancara yang dilakukan peneliti pada 3 informan, peneliti memperoleh jawaban yang beragam, seperti yang disampaikan oleh pelaku UMKM bidang kuliner yaitu:

"Yaaa menarik sih ya..., tentu pengurangan besaran pajak yang mesti dibayar sama kita pengusaha UMKM itu cukup berpengaruh ya 
sama psikologis kita. Awalnya mesti bayar 10 jutaan sekarang jadi 5 jutaan, lumayan lah. Peraturan baru ini menurut saya cukup membantu lah untuk UMKM baru, tapi sebener'e yang dibutuhkan sama kita itu bagaimana cara pemerintah membantu mempromosikan produk-produk UMKM. Soal'e kalau pake cara pengurangan pajak gini kan pendapatan pemerintah berkurang, tapi seandainya pemerintah membantu promosi produk UMKM secara nasional atau internasional misal'e, tentu itu kan menambah pendapatan negara sama membantu UMKM untuk berkembang jadi perusahaan besar." (Sdri. $\mathrm{Y}$, pengusaha kuliner)

Dari pernyataan tersebut tersirat bahwa yang diharapkan oleh pelaku UMKM tersebut bukanlah penurunan besaran tarif pajak, hal ini sejalan dengan penelitian Huda, 2015 yang menyatakan bahwa tarif pajak tidak berpengaruh secara parsial terhadap kepatuhan membayar pajak dan juga karena membayar pajak adalah kewajiban dari setiap wajib pajak maka pembayaran pajak tidak tergantung dari tarif pajak oleh karena itu dapat disimpulkan tarif pajak tidak mempengaruhi kepatuhan membayar pajak melainkan ada hal-hal lain seperti promosi produk-produk UMKM secara nasional yang menjadi harapan utama pelaku UMKM. Para pelaku UMKM juga berharap adanya implikasi yang dapat berdampak secara langsung terhadap mereka, karena dalam beberapa kejadian masih banyak kasus-kasus penggelapan pajak, seperti contohnya kasus korupsi Gayus, kasus korupsi E-ktp, sehingga masyarakat beranggapan bahwa pajak banyak dikorupsi oleh oknum pemerintahan dan memunculkan paradigma negatif di masyarakat sebagai bentuk kekecewaan terhadap pengelolaan pajak, hal ini mempengaruhi terhadap kesadaran masyarakat untuk membayar pajak. Para pelaku UMKM sebenarnya ingin mendapatkan imbal balik yang secara langsung berdampak pada diri mereka masing-masing (Aliyah, 2014). Pelaku UMKM tersebut beropini bila tarif pajak dikurangi maka pendapatan negara akan berkurang sehingga dapat mengganggu APBN. Sedangkan kalau pemerintah membantu peningkatan penjualan produk UMKM melalui promosi maka sektor UMKM dapat memberikan kontribusi pajak yang lebih besar daripada sebelumnya.
Sedangkan hasil wawancara pada informan yang lain yaitu pelaku UMKM di bidang asesoris, peneliti mendapatkan hasil sebagai berikut:

"Menarik dong.., pengurangan tarif pajak ini tentu meningkatkan keinginan saya untuk membuat usaha saya ini semakin besar, karena beban pajak yang harus saya bayar berkurang. Dengan begini uangnya bisa digunakan buat nambah barang, atau sewa tempat di mall-mall besar misal'e. Mungkin ini efek dari banyaknya online-online itu, biar UMKM nda lari semua ke online, kan.. online belum ada pajaknya." (Sdr. $\mathrm{CR}$, pengusaha asesoris)

Menurut informan ke-2, penurunan tarif pajak ini sangat menarik baginya. Penerapan PP No. 23 tahun 2018 memberikan angin segar bagi pengusaha UMKM karena pengurangan pajak dapat menunjang tumbuh kembang usahanya. Informan dari bidang asesoris ini memberikan catatan bahwa sektor UMKM perlahan mulai beralih dari sistem transaksi tradisional menuju ke sistem transaksi online dimana dalam pasar online tersebut belum dikenakan pajak oleh pemerintah.

Selanjutnya, informan ke 3 memberikan pendapat sebagai berikut:

"Menarik, peraturan baru ini mengurangi pajak yang harus saya bayar ke negara, kalo gini UMKM bisa lebih berkembang. $N d a$ harus bayar ini itu ke pemerintah. Ini tentu meningkatkan semangat pengusaha kecil untuk berusaha lebih keras, karena keuntungannya nda kepotong pajak kebanyakan." (Sdr. CH, distributor gelas)

Dari beberapa pernyataan dari 3 informan diatas dapat ditarik kesimpulan bahwa penerapan peraturan baru ini menarik bagi sektor UMKM. Pelaku UMKM merespon positif PP No. 23 tahun 2018 ini, bahkan menurut data, ada 311.197 wajib pajak baru terdaftar per 1 Juli 2018. Pertumbuhan wajib pajak baru untuk sektor UMKM ini cukup menggembirakan karena hal ini diyakini tidak terlepas dari penurunan tarif $\mathrm{PPh}$ final bagi pebisnis UMKM dari $1 \%$ menjadi $0,5 \%$. Akan tetapi pemerintah perlu mempersiapkan langkah selanjutnya bagi sektor UMKM agar tidak berbondong-bondong pindah ke pasar online, karena dengan tuntutan kemajuan teknologi dalam era revolusi industri 4.0 sektor UMKM perlu mengubah cara berbisnis mereka dimana dalam era ini semuanya serba online dan mudah diakses darimanapun 
sehingga masyarakat mulai meninggalkan model transaksi lama yaitu tatap muka. Apalagi untuk saat ini pemerintah belum memberlakukan tarif pajak bagi pelaku usaha di pasar online. Jika pemerintah tidak mempersiapkan ketentuan-ketentuan khusus untuk pasar online maka bukan tidak mungkin sektor UMKM akan pindah ke sana karena tarif pajak yang masih bebas. Hal ini tentunya berakibat pada menurunnya pendapatan negara dari sektor ini.

Dalam teori motivasi harapan Vroom, dijelaskan bahwa banyak faktor yang mempengaruhi apakah suatu individu termotivasi untuk meningkatkan produktivitas atau menurunkan usaha mereka, dalam hal penerapan PP no. 23 tahun 2018 ini ditemukan bahwa penurunan tarif pajak adalah salah satu faktor yang dapat meningkatkan keinginan pelaku UMKM untuk melaporkan pajak mereka. Dari hasil wawancara ditemukan bahwa teori ini berlaku bagi fenomena ini, dimana menurut para informan penerapan peraturan baru ini dapat memacu keinginan para pelaku UMKM untuk melaporkan besaran pajak mereka dengan harapan bahwa jumlah yang harus dibayarkan turun hingga setengah dari tarif normal.

Penurunan tarif pajak ini juga dimanfaatkan oleh pelaku UMKM untuk mengalokasikan selisih besaran pajak yang harus dibayar ke hal-hal lain yang menunjang usaha mereka, seperti keterangan Sdr. $\mathrm{CR}$, yang mengalokasikan selisih pembayaran tersebut untuk menyewa tempat usaha baru dan menambah jenis barang dalam usahanya. Dengan langkah-langkah penambahan insentif dan berbagai kemudahan yang diberikan bagi pelaku UMKM, pemerintah berharap sektor ini dapat meningkatkan usahanya dan menggerakkan roda ekonomi sektor dasar yang berhubungan langsung dengan masyarakat bawah hingga menengah.

\section{Pemahaman pelaku UMKM akan penerapan PP} No. 23 tahun 2018 yang bertujuan untuk meningkatkan keinginan memperbesar usaha mereka.

Dalam penelitian ini, peneliti menggunakan teori ekspektansi atau teori harapan yang dikemukakan oleh Victor Vroom tahun 1964, teori ini menyatakan bahwa tingkat kecenderungan suatu individu untuk melakukan sesuatu dengan cara tertentu tergantung pada tingkat harapan individu tersebut akan hasil yang pasti diterima dan pada daya tarik dari hasil suatu usaha (www.dictio.id).
Dalam pengertian lainnya, Vroom mengemukakan bahwa orang-orang akan termotivasi untuk melakukan hal-hal tertentu guna mencapai tujuan apabila mereka yakin bahwa tindakan mereka akan mengarah pada pencapaian tujuan tersebut dalam penelitian ini tujuan tersebut adalah meningkatnya usaha pelaku UMKM dan hal-hal tertentu tersebut adalah pemenuhan kewajiban pelaku UMKM kepada negara yaitu melaporkan dan membayar pajak penghasilan UMKM.

Setelah peneliti melakukan wawancara pada para informan diperoleh data sebagai berikut:

"Yaa... meskipun $n d a$ ada penurunan pajak ini kan kita pengusaha pasti kepingin usahanya tambah besar sama maju. Peraturan baru ini hanya mengurangi beban yang mesti ditanggung pengusaha UMKM." (Sdri. Y, pengusaha kuliner)

Menurut informan tersebut pengusaha UMKM memiliki keinginan agar usahanya semakin besar dan maju, namun pemberlakuan peraturan baru ini dapat membantu tujuan tersebut lebih cepat tercapai. Hal ini disebabkan beban yang harus ditanggung oleh pelaku usaha semakin berkurang. Sedangkan informan kedua memberikan pendapat sebagai berikut:

"Ada efeknya-lah untuk kedepannya, karena kan pajak tambah kecil otomatis usaha semakin mudah, cuma kita berharap supaya ngga ada peraturan-peraturan yang aneh-aneh supaya pengusaha ini nda malas mau besarin usaha. Sering soalnya kayak contohnya NIB sama SIUP, yang NIB kan diakui pusat atau OSS ya.. tapi di daerah mengakui SIUP, jadi aneh gitu. Padahal OSS kan aturan pusat, tapi daerah pakenya SIUP bukan NIB. " (Sdr. CR, pengusaha asesoris)

Dari wawancara terhadap informan dari UMKM asesoris tersebut diperoleh data bahwa pengusaha UMKM berharap supaya peraturan-peraturan yang berbelit dan tidak sinkron antara pusat dan daerah dapat disederhanakan. Akan tetapi, pengusaha UMKM setuju bahwa pemberlakuan PP No. 23 tahun 2018 ini meningkatkan keinginan usaha yang lebih baik pada pelaku UMKM. 


\section{Jurnal Akuntansi dan Pajak, 21 (01), 2020, 9}

"Kecil ya pengaruhnya. Kalau itu (memperbesar usaha) ya tergantung dari orangnya, mau nggak dia-nya tekun sama ulet. Pemerintah kan cuma kasi iming-iming pajak kecil." (Sdr. $\mathrm{CH}$, distributor gelas)

Pengusaha UMKM dari sektor distributor memberikan pendapat bahwa peraturan baru ini kurang memberikan dorongan bagi pelaku UMKM untuk meningkatkan semangat kerjanya karena menurutnya semangat untuk bekerja dan berusaha datang dari pribadi tiap pelaku UMKM. Pemerintah dalam hal ini hanya memberikan insentif berupa pengurangan pajak.

Pemerintah juga perlu untuk meringkas peraturan-peraturan yang ditujukan untuk sektor UMKM, karena sektor ini identik dengan kesederhanaan dan kemudahan bertransaksi sehingga jika terlalu banyak peraturan yang tumpang tindih antara pusat dan daerah dikhawatirkan akan memberatkan pelaku UMKM. Seperti yang dialami oleh Sdr. CR yang memberikan pendapat bahwa ada ketentuan yang berlaku dari pusat akan tetapi tidak berlaku di daerah sehingga dirasa sangat membingungkan bagi pengusaha UMKM yang sistem usahanya masih sederhana, dan berakibat banyak dari pelaku usaha sektor ini yang memiliki perijinan tidak lengkap.

Kesenjangan ketetapan peraturan antara pusat dan daerah ini dapat menjadi stigma negatif bagi pelaku UMKM terhadap pemerintahan, sehingga pelaku UMKM merasa bahwa semua yang berhubungan dengan pemerintahan itu pasti sulit dan berbelit-belit. Padahal kemudahan dalam memperoleh perijinan menjadi salah satu faktor utama agar para pengusaha dapat meningkatkan dan memperbesar usaha mereka.

Pemahaman pelaku UMKM akan penerapan PP No. 23 tahun 2018 yang bertujuan untuk meningkatkan kesadaran membayar pajak bagi pelaku usaha sektor UMKM.

Melalui pemberlakuan PP No. 23 tahun 2018, pemerintah melalui dirjen pajak juga berharap bahwa dengan peraturan baru ini maka pelaku UMKM yang belum pernah membayar pajaknya dapat menjadi wajib pajak baru karena kemudahan dan keringanan yang diberikan oleh pusat. Pada penerapan PP No. 46 tahun 2013, pelaku UMKM kurang merespon kemudahan-kemudahan yang diberikan oleh pemerintah, hal ini ditunjukkan dengan penurunan pertumbuhan wajib pajak baru sebesar $0,23 \%$ setelah penerapan PP no. 46 tahun 2013 (Hakim, 2015). Akan tetapi fenomena ini terjadi di KPP Pratama Manado, sehingga perlu penelitian-penelitian lainnya yang dilakukan di daerah-daerah lain untuk menunjang data tersebut. Terutama penelitian yang dilakukan di daerah yang memiliki populasi UMKM yang cukup besar, contohnya di D.I. Yogyakarta atau kota Surabaya yang menyandang status sebagai kota yang memiliki populasi UMKM terbesar ke 3 di Indonesia (BPS, 2016).

Dengan kenyataan tersebut maka peneliti melakukan wawancara pada informan mengenai kemungkinan bertumbuhnya persentase penambahan wajib pajak baru setelah pemberlakuan PP No. 23 tahun 2018 ini. Data yang diperoleh dari hasil wawancara kepada para informan diperoleh sebagai berikut:

"Menurut saya sih... Kalau untuk menambah jumlah wajib pajak baru kurang efektif ya, ini (PP No. 23 tahun 2018) sebener'e kan biar penyetor pajak yang lama-lama itu nda pindah ke bidang lain aja. Karena UMKM ini kan usaha yang istilah'e "barusan lahir" ya, kalo kebesaran pajak'e ya bisa-bisa tutup semua." (Sdri. Y, pengusaha kuliner)

Sedangkan informan ke-2 yang bergerak di bidang asesoris memberikan pernyataan sebagai berikut:

"Saya nda yakin sih kalau peraturan baru ini bisa menambah pembayar pajak baru ya.. karena $n d a$ ada insentif tambahan buat yang sudah rajin bayar, lebih ke kalau ketahuan (belum bayar pajak) baru kena teguran, jadinya ngga ada penarik minat UMKM buat laporin pajaknya. Jadi UMKM santai saja tunggu ada teguran tertulis baru lapor." (Sdr. CR, pengusaha asesoris)

Kedua informan memberikan pernyataan bahwa mereka tidak yakin penerapan PP No. 23 tahun 2018 ini dapat meningkatkan persentase pertumbuhan wajib pajak baru. Karena pelaku UMKM cenderung untuk ditegur terlebih dahulu oleh pihak yang berwenang baru setelah itu mereka akan membayar pajaknya. Apalagi jika UMKM tersebut baru berdiri, maka kemampuan finansialnya sangat terbatas untuk membayar pajak jika dipaksakan dan tarif pajak 
masih besar maka besar kemungkinan UMKM tersebut akan tutup. Sedangkan bagi UMKM penyetor pajak aktif, peraturan ini ditujukan untuk meringankan beban pajak mereka agar UMKM ini tidak beralih ke pasar online yang masih susah untuk dilacak besaran pajaknya. Sedangkan menurut informan ke 3 diperoleh data sebagai berikut:

"Tentunya bisa, apalagi kalau ditambah dengan sanksi jelas ke yang $n d a$ bayar pajak itu, jadi kalau tarif turun sama sanksi lebih tegas, pasti yang belum bayar itu jadi bayar semua." (Sdr. $\mathrm{CH}$, distributor gelas)

Menurut informan ke 3, penerapan peraturan baru ini dapat membantu meningkatkan jumlah penyetor pajak baru di sektor UMKM asalkan sanksi bagi penunggak pajak ditingkatkan. Pendapat dari informan ini sejalan dengan penelitian sebelumnya yang menemukan bahwa sanksi perpajakan secara parsial berpengaruh signifikan terhadap peningkatan kepatuhan Wajib Pajak UMKM sehingga dapat diinterpretasikan bahwa sanksi perpajakan berpengaruh terhadap kepatuhan wajib pajak UMKM dan persepsi Wajib Pajak terhadap sanksi yang akan dikenakan kepada dirinya semakin berat maka akan berpengaruh terhadap peningkatan kepatuhan Wajib Pajak UMKM (Fuadi, 2013). Untuk saat ini dirjen pajak masih memberikan kelonggaran pengawasan pajak bagi UMKM, kedepannya pemerintah perlu merancang sistem perpajakan yang tidak memberatkan bagi UMKM namun juga dapat mengundang wajib pajak baru dengan pemberian insentif-insentif atau reward bagi penyetor aktif pajak UMKM.

\section{Respon pelaku UMKM dan harapan di masa yang akan datang}

Penerapan PP no. 23 tahun 2018 ini telah memberikan angin segar bagi UMKM di Indonesia, dimana pemerintah telah menurunkan tarif pajak UMKM dari sebelumnya 1\% di PP no. 46 tahun 2013 menjadi 0,5\%. Jika di PP no. 46 tahun 2013 terdapat pro dan kontra dikarenakan tidak adanya kompensasi atas kerugian, dimana Wajib Pajak yang mengalami rugi tetap diberikan kewajiban pembayaran pajak, dan tidak ada nya istilah "NIHIL" dalam peraturan pemerintah tersebut karena pengenaan pajak dikenakan atas penghasilan bruto dan bukan atas penghasilan netto. Oleh karena itu, peneliti mengumpulkan data tentang respon positif masyarakat terhadap penerapan peraturan baru ini. Berdasarkan keterangan informan ke 1, diperoleh data sebagai berikut:

"Respon saya bagus, karena pemerintah cukup memperhatikan pengusaha-pengusaha kecil macam kita ini. Biar $n d a$ kesusahan bayar pajak yang akhirnya nunggak sama tutup usaha. Cuma kalau pajak dikurangi gini kan nanti pemasukan negara kurang, takutnya nanti dinaikin lagi." (Sdri. Y, pengusaha kuliner)

Sedangkan informan ke 2 memberikan keterangan sebagai berikut:

"Mungkin peraturan ini dibuat untuk mengimbangi toko online itu ya, yang online kan mau dibuat aturan perpajakannya. Lumayan lah mengurangi setengah yang harus dibayar ke negara, pemerintah memperingan tanggungan pengusaha kecil kalau gini." (Sdr. CR, pengusaha asesoris)

Kedua informan merespon baik pada peraturan baru ini, menurut mereka peraturan ini bisa membantu UMKM untuk meringankan beban yang harus mereka tanggung. Akan tetapi hal ini bisa mengurangi pendapatan negara yang kemudian berimbas pada APBN sehingga dikhawatirkan pengurangan tarif berdampak buruk di masa yang akan datang karena pembangunan bisa terhambat.

Berikutnya menurut informan ke-3, respon yang diberikan pelaku UMKM sebagai berikut:

"Menurut saya baik ya... Gini kan UMKM tidak terlalu terbebani sama pajak $1 \%$ yang dulu, sekarang dah turun jadi setengah persen. Kalau bisa ya seterusnya-lah $n d a$ usa syarat-syarat lagi." (Sdr. $\mathrm{CH}$, distributor gelas)

Sedangkan harapan yang diidam-idamkan oleh pelaku UMKM dari pemerintah sebagai pembuat kebijakan adalah:

"Harapan kami ngga tinggi-tinggi ya.. Peraturanperaturan dipermudah itu saja udah membantu banget. Utamanya peraturan-peraturan yang daerah sama pusat beda, itu bikin bingung kami pengusaha kecil. Di daerah peraturannya gini ternyata beda sama pusat, yang pusat harus begini. Jadi kami pengusaha ini serba repot, harus nurut yang mana. Kalau pajak itu kan baik tujuannya karena kan untuk pembangunan, $n d a$ diturunin juga sebetulnya nda papa sih." (Sdri. Y, pengusaha kuliner) 


\section{Jurnal Akuntansi dan Pajak, 21 (01), 2020, 11}

Pelaku UMKM yang pertama menyatakan bahwa banyak peraturan-peraturan yang seharusnya dapat diperingkas sehingga tidak memberatkan pelaku UMKM yang mayoritas tidak berlatar belakang pendidikan tinggi, karena semakin besar UMKM maka akan semakin sering pelaku usaha tersebut akan memerlukan perijinan-perijinan yang disyaratkan oleh negara. Hal senada juga disampaikan oleh informan ke-2, berikut isi penjelasan informan tersebut:

"Harapan saya.. ya.. agar pengurusan dokumendokumen penunjang usaha saya itu lebih dipermudah, syarat-syaratnya yang banyak macemnya itu dibuat sedikit mungkin sama bisa online. Itu bakal sangat menunjang saya dan pengusaha lain yang baru mulai usaha." (Sdr. $\mathrm{CR}$, pengusaha asesoris)

Lalu informan ke-3 memberikan pernyataan sebagai berikut:

"Birokrasi-nya disamakan untuk nasional. Jadi syarat usaha di Medan bisa sama seperti Surabaya. Kalau sama semua gitu enak, UMKM ini bisa buka usaha di mana aja, nggak kena peraturan yang beda-beda tiap daerah. Sama sistem onlinenya dibenahi supaya nggak kalah sama negara sebelah, yang mana internetnya jauh lebih bagus dari Indonesia. Di Singapore bikin ijin usaha cuma 1 jam selesai lho.." (Sdr. $\mathrm{CH}$, distributor gelas)

Dari pernyataan informan ke-3 dapat ditarik kesimpulan bahwa pelaku UMKM berharap agar birokrasi dan peraturan-peraturan bagi sektor UMKM dipermudah. Hal ini medukung temuan pada penelitian sebelumnya yaitu adanya kemudahan dan penyederhanaan peraturan dapat membantu masyarakat khususnya para pengusaha UMKM dalam membayar pajaknya (Resyniar, 2014). Pemerintah perlu menyadari bahwa sektor UMKM identik dengan kesederhanaan, mereka tidak memiliki sumber daya yang cukup besar untuk menghadapi syarat-syarat perijinan yang begitu banyak seperti yang dirasakan oleh ketiga informan tersebut.

\section{KESIMPULAN}

Penelitian ini menghasilkan beberapa hasil kesimpulan yang dirangkum berdasarkan keterangan dari pelaku UMKM. Yang pertama, sosialisasi peraturan baru kurang maksimal dirasakan oleh pelaku UMKM. Banyak dari pelaku UMKM kurang memahami akan adanya pemberlakuan peraturan yang baru serta isi dan syarat-syarat yang berlaku dari peraturan tersebut secara mendetail. Pelaku UMKM cenderung lebih pasif dalam urusan pajak penghasilannya karena menurut pelaku UMKM berurusan dengan hal-hal yang berhubungan dengan perpajakan itu adalah hal yang ribet.

Kedua, pemberlakuan PP no. 23 tahun 2018 menarik bagi pelaku UMKM. Peraturan baru ini memberikan keringanan tanggungan pajak penghasilan bagi pelaku UMKM, akan tetapi PP no. 23 tahun 2018 ini dirasa oleh pelaku UMKM hanya sebagai pemanis dari pemerintah agar pelaku UMKM tidak beralih ke sistem transaksi online. Karena sampai saat ini pemerintah belum menetapkan besaran pajak jika terjadi transaksi jual beli barang secara online sehingga dapat dikatakan sistem online masih bebas pajak. Dikhawatirkan jika UMKM berbondong-bondong beralih menggunakan sistem online sebagai media utama transaksinya maka negara akan kehilangan pendapatan yang cukup signifikan.

Ketiga, penerapan PP no. 23 tahun 2018 meningkatkan keinginan untuk berusaha para pelaku UMKM. Untuk meningkatkan iklim usaha sektor UMKM diperlukan kerjasama baik dari pemerintah pusat maupun daerah, karena jika peraturan-peraturan untuk sektor UMKM di daerah masih berbelit-belit maka insentif pengurangan pajak penghasilan ini kurang dapat memberikan hasil maksimal. Sinkronisasi perijinan antara pusat dan daerah diperlukan, dan perampingan peraturan-peraturan yang tumpang tindih di daerah-daerah juga akan sangat membantu sektor UMKM berkembang lebih cepat.

Keempat, melalui PP no. 23 tahun 2018, pemerintah berharap dapat menarik penyetorpenyetor pajak baru dari sektor UMKM, tetapi sektor UMKM identik dengan kesederhanaan transaksi dan kearifan lokal sehingga peraturan dari pusat saja dianggap kurang untuk dapat menarik penyetor pajak baru. Dibutuhkan kerjasama antara pusat dan daerah untuk dapat meningkatkan penerimaan negara dari sektor ini, karena setiap daerah memiliki keunikan khusus daerah tersebut, dan yang diharapkan oleh pelaku UMKM bukan hanya insentif tarif pajak saja tetapi support dari pemerintah daerah. Pemberian sanksi tegas bagi penunggak pajak diharapkan memberikan efek positif bagi peningkatan penyetor 
pajak agar penerimaan pajak dari sektor ini dapat meningkat.

Kelima, pelaku UMKM merespon positif pemberlakuan PP no. 23 tahun 2018. Peraturan ini memberikan keringanan bagi penyetor aktif pajak penghasilan final dengan turunnya tarif pajak, tetapi dengan turunnya tarif pajak maka penerimaan negara juga akan mengalami penurunan. Apalagi dengan revolusi industri 4.0 yang memanfaatkan teknologi seperti IoT (Internet of Things) tren toko online dimana masyarakat cenderung lebih suka untuk bertransaksi secara online meningkat. Sedangkan pemerintah belum siap untuk menghadapi revolusi industri ini, hal ini terlihat dari belum adanya ketentuan perpajakan di sektor ini.

Keenam, pelaku UMKM mendapat keringanan tarif pajak yang dapat membantu mereka mengembangkan usahanya dengan menggunakan selisih jumlah yang harus dibayarkan ke bentukbentuk investasi lain seperti membeli atau menyewa tempat usaha yang baru atau memperkaya jenis dan varian barang yang dijual. Dengan demikian tujuan dari pengimplementasian peraturan baru ini tercapai dengan meningkatnya kesejahteraan pelaku UMKM.

\section{REFERENSI}

Ananda, P. R. D. 2015. Pengaruh Sosialisasi Perpajakan, Tarif Pajak, dan Pemahaman Perpajakan Terhadap Kepatuhan Wajib Pajak (Studi pada UMKM yang Terdaftar sebagai Wajib Pajak di Kantor Pelayanan Pajak Pratama Batu). Jurnal Perpajakan 6(2): 1-9.

Anatan, L. 2010. Telaah Kritis Expectancy Theory Victor Harold Vroom. Jurnal Manajemen 9(2): 19-30.

Arikunto, Suharsimi. 2016. Prosedur Penelitian: Suatu Pendekatan Praktik. Rineka Cipta. Jakarta.

Badan Keahlian DPR RI. 2018. Perkembangan Realisasi Penerimaan Perpajakan Periode 2013-2018 dan Target Dalam RAPBN 2019. Pusat Kajian Anggaran. Jakarta.

Badan Pusat Statistik. 2016. Tabel Perkembangan UMKM pada Periode 1997-2013. Desember. BPS Indonesia. Jakarta.

Creswell, J.W. 1998. Qualitative inquiry and research design: Choosing among five traditions. Thousand Oaks. Sage Publication.
Eerde, W. V. dan Henk T. 1996. Vroom's Expectancy Models and Work Criteria : A MetaAnalysis. Journal of Applied Psychology . 81(5):575-586.

Gunarto, E. 2018. PPh Final UMKM : Perbedaan PP 46 Tahun 2013 dengan PP 23 Tahun 2018. https://forumpajak.org. 18 Februari 2019 (15.05).

Huda, A. 2015. Pengaruh Persepsi Atas Efektifitas Sistem Perpajakan, Kepercayaan, Tarif Pajak, dan Kemanfaatan NPWP Terhadap Kepatuhan Membayar Pajak (Studi Empiris Pada Wajib Pajak UMKM Makanan di KPP Pratama Pekanbaru Senapelan). Jurnal Online Mahasiswa 2(2): 1-15.

Kementerian Koperasi dan Usaha Kecil Menengah (KKUKM). 2016. Laporan Kinerja Kementerian Koperasi dan Usaha Kecil Menengah (KKUKM). Tahun 2015. Kementerian Koperasi dan Usaha Kecil Menengah (KKUKM). Jakarta.

Keziana. 2016. Analisis Penerapan PP No. 46 tahun 2013 Terhadap Tingkat Kepatuhan Wajib Pajak dan Penerimaan PPh Final (Studi di Kantor Pelayanan Pajak Pratama Kepanjen). Jurnal Riset Mahasiswa Akuntansi 4(2): 1-14.

Lembaga Pengembangan Perbankan Indonesia. 2015. Profil Bisnis Usaha Mikro, Kecil, dan Menengah (UMKM). Tahun 2015. Bank Indonesia. Jakarta.

Marjono. 2014. PP No.46 Tahun 2013 Tidak Adil dan Tidak Pro Pengusaha Kecil. http://majalahukm.com/pp-no-46-tahun-2013tidak-adil-dan-tidak-pro-pengusaha-kecil/. 20 Maret 2019 (19.35).

Miles, B. Mathew dan Michael Huberman. 1992. Analisis Data Kualitatif Buku Sumber Tentang Metode-metode Baru. UIP. Jakarta.

Moleong, L.J. (2011). Metodologi Penelitian Kualitatif Edisi Revisi. Remaja Rosdakarya. Bandung.

Nazir, M. 2005. Metode Penelitian. Galia Indonesia. Bogor.

Novliemyanti, J. 2017. Justice Tax Based On MSME Enterpreneur Perspective Case Study Of Atom Market Surabaya. The International Journal of Organizational Innovation 10(1): 260-274.

Peraturan Pemerintah Nomor 46 Tahun 2013. Pajak Penghasilan Atas Penghasilan Dari Usaha yang Diterima atau Diperoleh Wajib Pajak yang Memiliki Peredaran Bruto Tertentu. 12 Juni 2013. Lembaran Negara Republik Indonesia Tahun 2013 Nomor 106. Jakarta. 


\section{Jurnal Akuntansi dan Pajak, 21 (01), 2020, 13}

Peraturan Pemerintah Nomor 23 Tahun 2018. Pajak Penghasilan Atas Penghasilan Dari Usaha yang Diterima atau Diperoleh Wajib Pajak yang Memiliki Peredaran Bruto Tertentu. 8 Juni 2018. Lembaran Negara Republik Indonesia Tahun 2018 Nomor 89. Jakarta.

Prawagis, F. D. 2016. Pengaruh Pemahaman Atas Mekanisme Pembayaran Pajak, Persepsi Tarif Pajak, dan Sanksi Pajak Terhadap Kepatuhan Wajib Pajak UMKM (Studi Pada WP yang Terdaftar di KPP Pratama Batu). Jurnal Perpajakan 10(1): 285-293.

Resyniar, G. 2014. Persepsi Pelaku Usaha Mikro Kecil Menengah Terhadap Penerapan PP. 46 Tahun 2013. Jurnal Ilmiah Mahasiswa FEB 2(2).

Sugiyono. 2010. Metode Penelitian Kuantitatif Kualitatif dan $R \& D$. Alfabeta. Bandung.

Susilo, E. J. 2014. Pemahaman Wajib Pajak Terhadap Peraturan Pemerintah No. 46 Tahun 2013 Tentang Pajak UKM (Studi Kasus Pada Wajib Pajak yang Terdaftar di Kantor Pelayanan Pajak Pratama Palembang Ilir Barat). STIE MDP. Palembang.
Syahdan, S. A. 2014. Dimensi Keadilan Atas Pemberlakuan PP No. 46 Tahun 2013 dan Peningkatan Kepatuhan Wajib Pajak. Jurnal Bisnis dan Akuntansi : Infestasi 10(1): 64-72.

Tambunan, T. H. 2009. UMKM di Indonesia. Ghalia Indonesia. Bogor.

Yuesti, A. 2017. Akuntansi Keperilakuan. Abpublisher. Yogyakarta.

Yuniarta, L. 2019. Wajib Pajak dari Sektor UMKM Bertambah Setelah Tarif $\mathrm{PPh}$ Dipangkas. https://insight.kontan.co.id/news/wajib-pajakdari-sektor umkm-bertambah-setelah-tarif-pphdipangkas-menjadi-1. 05 Agustus 2019 (20.38).

Yusra, M. 2016. Modul Akuntansi Keperilakuan. http://repository.unimal.ac.id. 18 Februari 2019 $(20: 43)$. 